Authors: Jan Burek, Paweł Sułkowicz, Robert Babiarz

Title of article: „Pomiar i kompensacja walcowości wałków o małej sztywności w procesie szlifowania osiowego” (“Cylindricity error measurement and compensation in traverse grinding of low-stiffness shafts")

Mechanik, Vol. 91, No. 11 (2018): pages 970-972

DOI: https://doi.org/10.17814/mechanik.2018.11.172

\title{
Cylindricity error measurement and compensation in traverse grinding of low-stiffness shafts
}

\author{
Pomiar i kompensacja walcowości wałków o małej \\ sztywności w procesie szlifowania osiowego
}

\section{JAN BUREK \\ PAWEK SUKKOWICZ ROBERT BABIARZ *}

This paper presents a system of measurement and compensation of cylindricity error in low-stiffness shafts grinding. A programme, that generates the path of a grinding wheel taking into account the elastic deformation of the shaft and grinding machine on the basis of the grinding force measurement was developed

KEYWORDS: traverse grinding, cylindrical grinding, cylindricity error, cylindricity measurement

Axio-symmetric parts account for nearly half of the parts manufactured for the needs of the engineering industry. Among them, about $12 \%$ are shafts with low stiffness, i.e. those in which the length-to-diameter ratio $l / d$ is greater than 10. They are used in many industries, including in the aviation industry (turbine shafts, spring shafts, elastic and torsional shafts), tool (drills, reamers, special tools), machine tools (rotor, pumps and generators shafts, guides) or automotive (driveshafts, axle-shafts) [1, 2].

Shafts with low stiffness are usually made of highstrength alloy steels. Typical methods of their machining include external turning and grinding. Turning machining should provide $8 \div 11$. tolerance class and roughness $R a=$ $0.63 \div 2.5 \mu \mathrm{m}$, while grinding operation - 5th or 6th tolerance class for roughness $R a<0.63 \mu \mathrm{m}$ [3].

The low stiffness of parts causes problems with achieving the required shape and dimensional accuracy. During grinding of such parts, elastic deformation occurs, resulting in errors in the cylindricity and dimension of the parts being made [4].

Many studies show that the pliability of the tailstock and headstock centers and the workpiece whose length / diameter ratio is greater than 10 is about $90 \%$ of the total machine tool - tool - workpiece system's pliability [5]. Fig. 1 shows the elastic displacements of these elements.

The elastic displacement of the workpiece $x_{1}$, resulting from the displacements of the headstock center $x_{\mathrm{w}}$ and the tailstock center $x_{\mathrm{k}}$ can be calculated from the following equation:

$$
x_{1}=\left(1-\frac{z}{l}\right)^{2} \cdot \frac{F_{\mathrm{n}}}{k_{\mathrm{w}}}+\left(\frac{z}{l}\right)^{2} \cdot \frac{F_{\mathrm{n}}}{k_{\mathrm{k}}}
$$

where: $k_{\mathrm{w}}$ - stiffness of the center of the headstock, $k_{\mathrm{k}}$ stiffness of the tailstock center, $F_{\mathrm{n}}$ - normal component of the grinding force.

*dr hab. inż Jan Burek, prof. PRz (jburek@prz.edu.pl), mgr inż. Paweł Sułkowicz (sulkowicz@prz.edu.pl), dr inż. Robert Babiarz (robertb@prz.edu.pl), Katedra Technik Wytwarzania i Automatyzacji, Wydział Budowy Maszyn i Lotnictwa, Politechnika Rzeszowska.

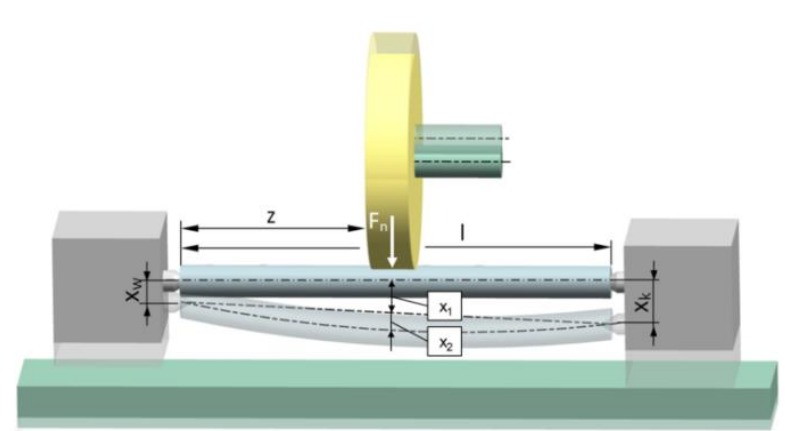

Fig. 1. Elastic deformation of the workpiece as well as headstock and tailstock centers

Moreover, the deflection of the object is determined as follows:

$$
x_{2}=\frac{F_{\mathrm{n}} \cdot z^{2} \cdot(l-z)^{2}}{3 \cdot E \cdot I \cdot l}
$$

where: $E$ - Young's modulus; I - moment of inertia of a circular cross-section.

The total value of the displacement of the elastic system at any point of the ground workpiece of low rigidity can be roughly superimposed as the sum of the relations (1) and (2). As a result of this deformation dimensional errors and cylindricity errors of the ground parts arise. Deformation of the grinding machine centers cause taper error, and the deflections of the workpiece - barrel error.

The reduction of the dimension and shape errors of ground low stiffness shafts in industrial practice is achieved in two ways. The first consists of reducing the value of the grinding force thanks to the use of low technological parameters (values of the axial feedrate $v_{\mathrm{fa}}$ and the infeed of the grinding wheel $a_{\mathrm{e}}$ - increasing the number of grinding wheel passes). However, this is uneconomical due to the significant amount of the machining time. The second method is the use of steadies (fixed or mobile). Unfortunately, setting them up is time-consuming and involves the risk of damaging the surface, and in the case of movable steadies is also associated with higher costs, because it is necessary to use an additional servo drive. Therefore, there is a need for such solutions in controlling the path of the grinding wheel, which will ensure compensation of the elastic deformation of the object, especially in the case of CNC grinding machines, in which it 
is possible to control the grinding wheel position in the $X$ axis.

\section{Aim of the work}

The aim of the authors was to develop and test the measurement system for cylindricity deviation of low stiffness shafts, and to compensate for this deviation. To compensate for the deviation, a method was developed to control the infeed of the grinding wheel during longitudinal grinding based on the measured values of the $F_{\mathrm{n}}$ component of the grinding force. The block diagram of the measurement and control system is shown in fig. 2 .

When grinding the first part (as a test), the normal component of the $F_{\mathrm{n}}$ grinding force is measured. Based on the recorded force values, the displacement of the elastic system is calculated. Next, a program is generated which controls the path of the grinding wheel, which is implemented into the machine tool control system - the next object is already ground with the grinding wheel infeed adjustment. Due to the change in cutting properties of the grinding wheel (its wear), this process is repeated for each subsequent workpiece machined during the grinding wheel life time. The values of cylindricity deviations of each part are measured after machining on a machine tool using an inductive sensor.

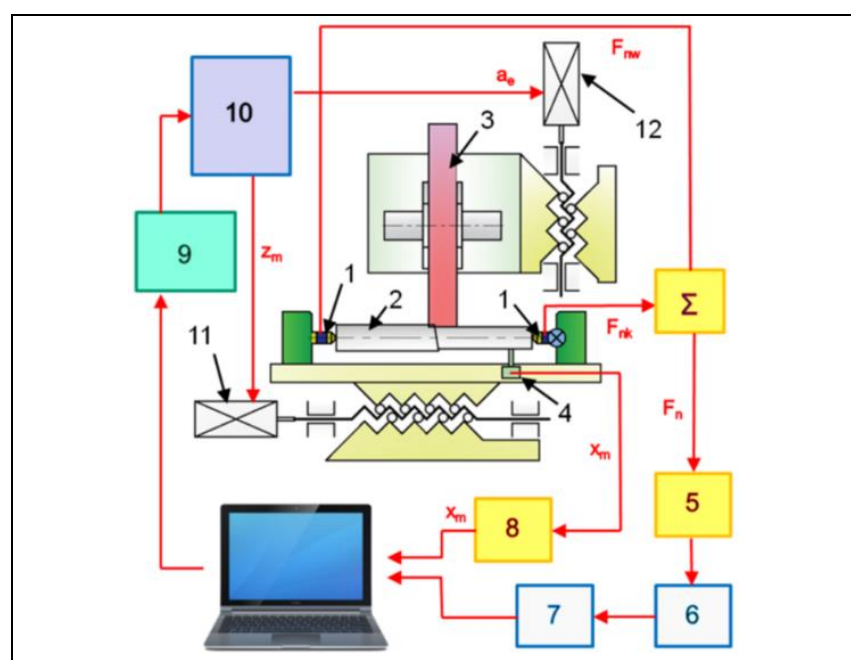

Fig. 2. Block diagram of the measurement and compensation of deviations of cylindricity system: 1 - dynamometer, 2 - test part, 3 grinding wheel, 4 - inductive sensor, 5 - bridge circuit, 6 - digital filter, 7 - A/D converter, 8 - shape measurement system, 9 adapting system, 10 - machine tool control system, $11-Z$ axis motor, 12 - $X$ axis drive motor

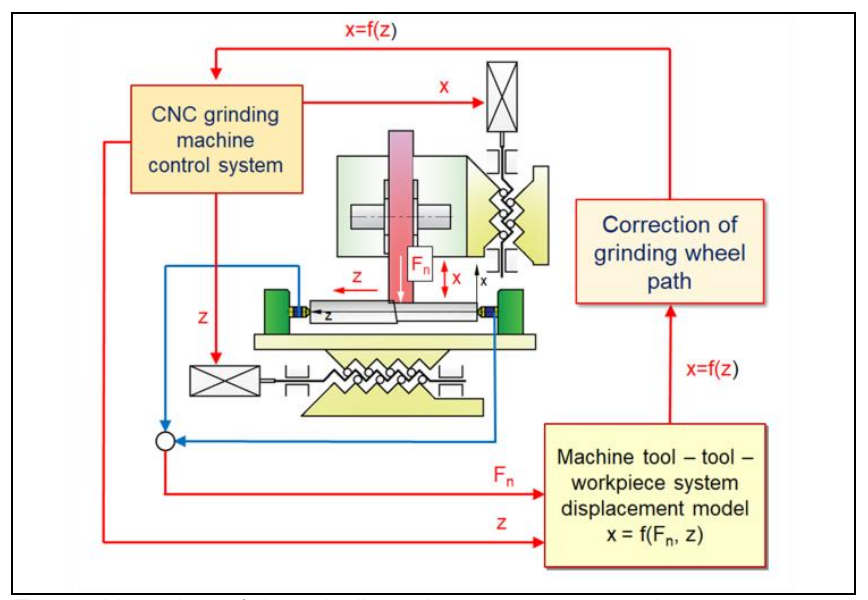

Fig. 3. Algorithm of the grinding wheel motion control system
This way it is possible to obtain information about current errors, which allows to make corrections to the program that generates the next path trajectory of the grinding wheel in the $X$ axis for the next part. The algorithm of the grinding wheel path control system is shown in fig. 3 .

\section{Test conditions}

The test stand was made on the basis of a three-axis RS 600 C grinding machine by Geibel \& Hotz, CNC controlled (fig. 4).

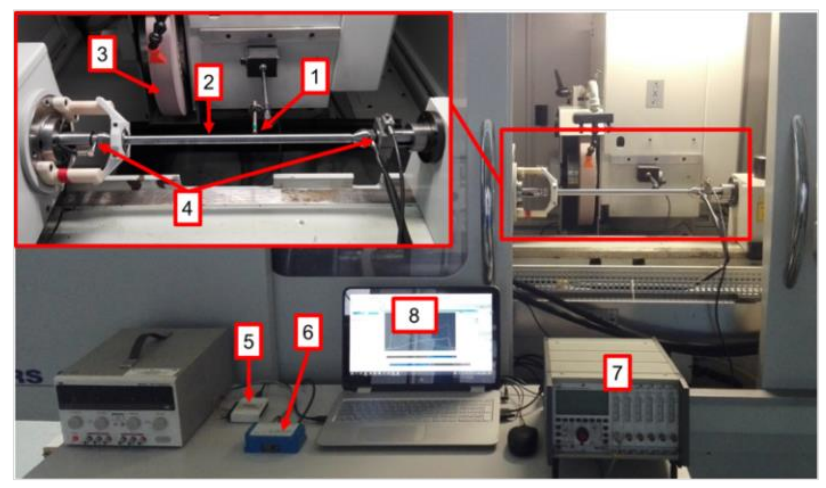

Fig. 4. Test stand: 1 - inductive sensor, 2 - test part, 3 - grinding wheel, 4 - dynamometers, 5 - A/D converter, 6 and 7 - amplifiers, 8 - computer

Experimental tests consisted of longitudinal grinding without correction and with correction of the grinding wheel path - of the test part with length $I=400 \mathrm{~mm}$ and diameter $d$ $=22 \mathrm{~mm}$. The part made of $40 \mathrm{H}$ steel was mounted in the machine tool in the centers of Kistler's circular ring force piezoelectric sensors, allowing the measurement of three components of grinding force. In order to eliminate the influence of the torque of the driver on the measurement of the grinding force, a two-armed grinding carrier was used, specially designed for this purpose. The waveforms of measured signals were recorded in the LabVIEW SignalExpress program. The tests were carried out using an electro-corundum grinding wheel type M60H12VE01PI-45 with a diameter of $d_{\mathrm{s}}=400 \mathrm{~mm}$ and a width of $b_{\mathrm{s}}=50 \mathrm{~mm}$. Wheel speed was $v_{c}=35 \mathrm{~m} / \mathrm{s}$, and workpiece - $v_{\mathrm{w}}=23$ $\mathrm{m} / \mathrm{min}$. Grinding infeed was equal to $a_{\mathrm{e}}=0.06 \mathrm{~mm}$. The part was ground at an axial feed of $f_{\mathrm{a}}=4 \mathrm{~mm} / \mathrm{rev}$.

\section{Results}

The measured deviations of the profile of the test part, ground without correction and with correction of the grinding wheel path, are shown in fig. 5.

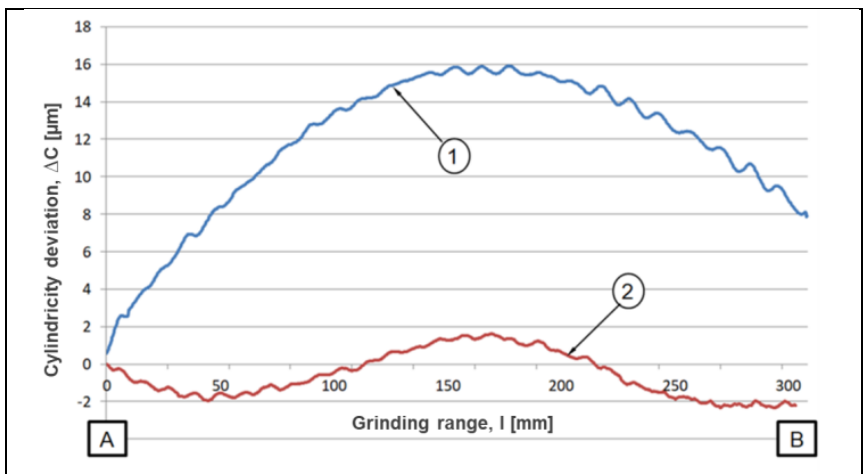

Fig. 5. Course of the deviation of the test part profile, measured on the machine tool: 1 - grinding without correction, 2 - grinding with correction of grinding wheel motion, $A$ - side of the headstock, $B$ side of the tailstock 


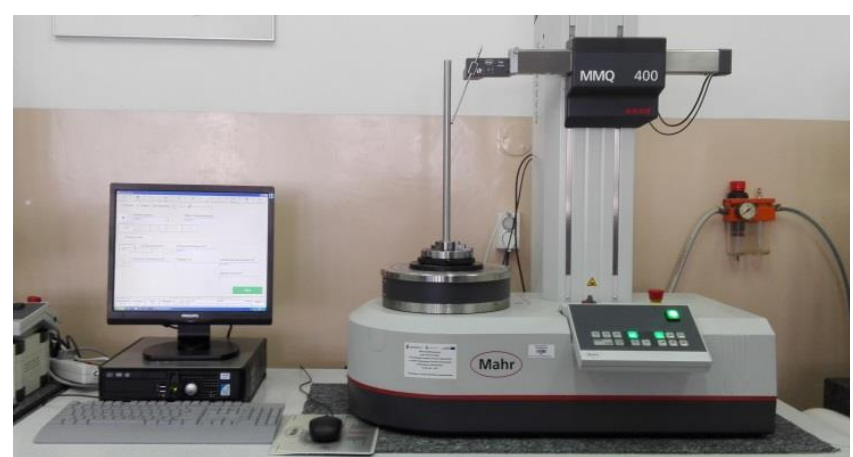

Fig. 6. Measurement of deviation of the part's cylindricity on a MarForm MMQ 400

Due to the way of mounting the part, the grinding path was slightly shorter and amounted to approx. $300 \mathrm{~mm}$. The profile of the part was measured six times - every $60^{\circ}$. using an inductive sensor mounted on the machine tool's spindle. The measurements were made by moving the grinding machine table together with the part relative to the inductive sensor, on the cylindrical surface of the part along the axis of the part, at velocity $v_{\mathrm{m}}=100 \mathrm{~mm} / \mathrm{min}$.

It can be noticed that the application of the correction of the grinding wheel's path resulted in a marked improvement in the accuracy of the machined workpiece. In the case of grinding without correction of the grinding wheel's path, higher values of deviations in the profile of the ground part were obtained on the side of the tailstock center, which results from its lower stiffness compared to the stiffness of the headstock center.

The cylindricity deviation measured with the use of an inductive sensor for the grinding without the correction of the grinding wheel's path was approx. $16 \mu \mathrm{m}$. The application of the correction of the grinding wheel's path by controlling its infeed in the $X$ axis to compensate for the elastic displacement made it possible to reduce the cylindricity deviation to approx. $4 \mu \mathrm{m}$. In order to confirm the measurements of cylindricity deviations of ground parts,

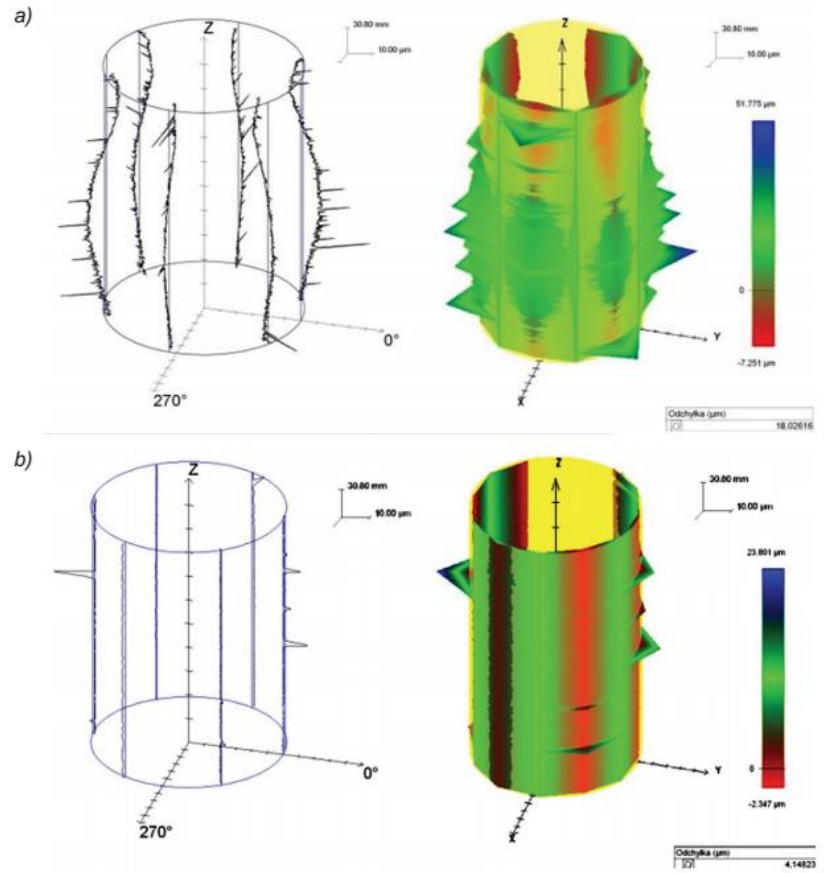

Fig. 7. Results of the measurement of cylindricity deviation of the test object measured on a universal form measuring machine: a) grinding without correction of grinding wheel's path, b) grinding with path correction measurements were also carried out on a MarForm MMQ 400 universal form measuring machine (fig. 6).

Measurements were carried out using the longitudinal cross-section strategy, similarly to measurements on a grinding machine, measuring the profile of the object six times every $60^{\circ}$ (fig. 7 ).

In the case of grinding without correction of the grinding wheel's path, a cylindricity deviation of approx. $18 \mu \mathrm{m}$ was obtained. For grinding with the correction of wheel's path, the measured deviation was approx. $4 \mu \mathrm{m}$. Comparing the obtained results, it can be concluded that an inductive sensor mounted on the grinding machine spindle can be successfully used to measure the cylindrical deviation of ground parts directly on the grinding machine.

\section{Conclusions}

During longitudinal grinding of shafts with low stiffness without steadies, elastic deformation of the machine tool tool - workpiece system takes place, and consequently, cylindrical deviations of the ground parts occur. Modern CNC grinding machines allow to program any grinding wheel's path. The tests show that it is possible to control the infeed of the grinding wheel during longitudinal grinding of shafts with low stiffness in a way that will allow to significantly reduce the errors of cylindricity of the workpieces.

The application of the correction of the grinding wheel's path during longitudinal grinding of the test part allowed for a four-times reduction of the cylindricity deviation. The measurements on the universal form measuring machine showed a high correlation with the measurements carried out on the machine tool. It can therefore be concluded that an inductive sensor, mounted on the grinding wheel's spindle, after appropriate calibration, provides a sufficiently accurate measurement of the cylindricity deviation.

\section{REFERENCES}

1. Świć A. „Technologia obróbki wałów o małej sztywności”. Lublin: Wydawnictwo Politechniki Lubelskiej, 2009.

2. Draczow A. Taranenko G., Hałas W. „Sterowanie układem dynamicznym obróbki części osiowosymetrycznych o małej sztywności". Pomiary, Automatyka. Robotyka. 2 (2009): pp 125-131.

3. Oczoś K., Habrat W. „Doskonalenie procesów obróbki ściernej. Cz. II. Wysokoefektywne ściernice i procesy szlifowania". Mechanik. 8-9 (2010): pp. 517-529.

4. Cieniuszek W., Świć A. „Analiza porównawcza badań teoretycznych i eksperymentalnych sterowania dokładnością szlifowania wałków o małej sztywności. Problemi tekhniki. Nauchnovirobochnyjj zhurnal. 2 (2004): pp. 239-242.

5. Burek J. „Regulacja i nadzorowanie procesu szlifowania wgłębnego walcowych powierzchni zewnettrznych". Rzeszów: Oficyna Wydawnicza Politechniki Rzeszowskiej, 2017.

Translation of scientific articles, their computer composition and publishing them on the website www.mechanik.media.pl by original articles in Polish is a task financed from the funds of the Ministry of Science and Higher Education designated for dissemination of science.

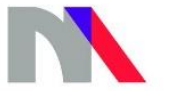

Ministry of Science and Higher Education Republic of Poland 